\title{
Indonesian Adaptation of the Passion Scale
}

\author{
Puspita Puji Rahayu ${ }^{1}$, Priscilla Titis Indiarti ${ }^{2}$, Karyono $^{3}$ \\ Faculty of psychology, Universitas Nasional Karangturi, \\ Semarang, Central Java, Indonesia ${ }^{1,2,3}$ \\ \{puspitapujirahayu@gmail.com ${ }^{1}$ \}
}

\begin{abstract}
The study of measuring instrument adaptation aims to discover types of working passion (harmonious passion and obsessive passion) owned by Indonesian employees. The research participants were taken from 114 employees of a media company in Indonesia using purposive sampling technique. There are 7 items of harmonious passion and 7 items of obsessive passion in Passion Scale measuring instrument. Passion Scale is a measuring instrument which were initially created in French, and were translated into English. Back-translation is necessary so that cross-cultural study could possibly be conducted [1] (Marsh et al., 2013). Thus, it is important to ensure that the measuring instrument may be applied in Indonesia due to cultural and linguistic differences. Beaton introduced several stages of measuring instrument adaptation: translation, synthesis, back-translation, expert committee review, and pretest [2]. From the result, reliability score for harmonious passion is 0.851 while reliability score for obsessive passion is 0.719 . However, it was found that the reliability score for Passion Scale and the adapted version of Passion Scale was different. The difference implies that passion is a measurement which needs to be adjusted to the culture where a research took place.
\end{abstract}

Keywords: Passion Scale Adaptation, Harmonious Passion, Obsessive Passion

\section{Introduction}

Persons who have persistence, positive emotions, and well-being forms at work, when are assessed from the cognitive and affective side of the work and organization in order to produce intentions and behaviors which are consistent at work, can be said as employees who have a passion at work [3]. Passion is defined as a strong tendency towards an activity that is preferred and considered important, where persons spend time and energy on that activity regularly [4]. Dualistic Passion Model (DMP) is the argument to explain the full involvement of employees at their work, the DMP is divided into two categories, which are Harmonious Passion (HP) and Obsessive Passion (OP) [5]. A measuring tool which can be used to measure Dualistic Model Passion is the Passion Scale. This measurement was made by Robert J. Vallerand in 2003, having 7-item subscales on Harmonious Passion and 7-item subscales on Obsessive Passion [6]. Vallerand is a social psychology professor at Université du Québec à Montréal and has been the President of The Canadian Psychological Association and The International Positive Psychology Association [7]. 
The passion categories division is based on different employee engagement processes. Harmonious passion is a type of passion where persons are bound in an activity that is in accordance entirely with their wishes, bound by activities that do not trigger conflict with other parts of life and persons can still control their passion [8] therefore employees are fully engaged with work based on pleasure and the desire to develop themselves [5]. Another thing with obsessive passion is an individual's attachment to an activity and occurs due to intra and interpersonal pressure, which is bound by activities that divert time and reason from an individual's life [8], therefore the employees are involved in work for self-esteem reasons or the so-called secondary benefits [5].

The passion types whose employees have can be distinguished by their involvement at work, and this has become the focus of researchers to adapt the Passion Scale measurement tool to conduct research on employees in Indonesia. This Passion Scale adaptation is also caused by passion as an intrinsic passion bound to the lives of individuals in the community therefore this research can be applied in real phenomena in the context of work life and work itself [9]. Overall, according to Vallerand this study of passion shows that employees with harmonious passion tend having emotional and characteristics process with positive results and vice versa, employees with obsessive passion having tendency toward emotional and characteristics process with more negative results [9].

DMP caused different phenomena in organizations. DMP can identify the type of passion owned by employees. Previous research has shown harmonious passion will have a positive effect, while obsessive passion has more negative impact on the organization [10]. The different impacts produced by each DMP can be overcome by the organization through the measurement process. Adaptation of this measuring instrument formulates a problem statement to identify the type of passion which Indonesian employees have and how it affects the organization.

The adaptation process is carried out with the aim that the passion gauge at work can be adapted to the research sample which will use this measurement tool. After going through the adaptation process, this measurement tool will be given to the population and sample in Indonesia. The population of this research is Indonesian employees, with employees in Indonesia who work in media companies as the sample.

\section{Method}

The sampling method in this study is non probability sampling, where the probability of a population member being chosen is unknown [11]. The non probability sampling method used is purposive sampling, which is a method for sampling which only matches the criteria of the research sample [11]. In this study, the sample is employees who work in various departments of the media company to match the research criteria even though the probability of selected population members is unknown.

\subsection{Sample}

The total samples of this study were 114 participants. The data collection process is carried out using an online survey. Questionnaires are given to employees who work in media companies in Indonesia. 


\subsection{Prosedure}

Adaptation to the measuring instrument required because many of the questionnaires developed came from countries which using English. Cross-cultural adaptation will help to eliminate biased results and adapt them to the culture of each country. When a measuring instrument will be used in countries, languages, and cultures which are different from the original, then cross-cultural adaptation required [2]. The adaptation stages of measuring instruments according to Beaton are translation, synthesis, back translation, expert committee review, and pretest [2].

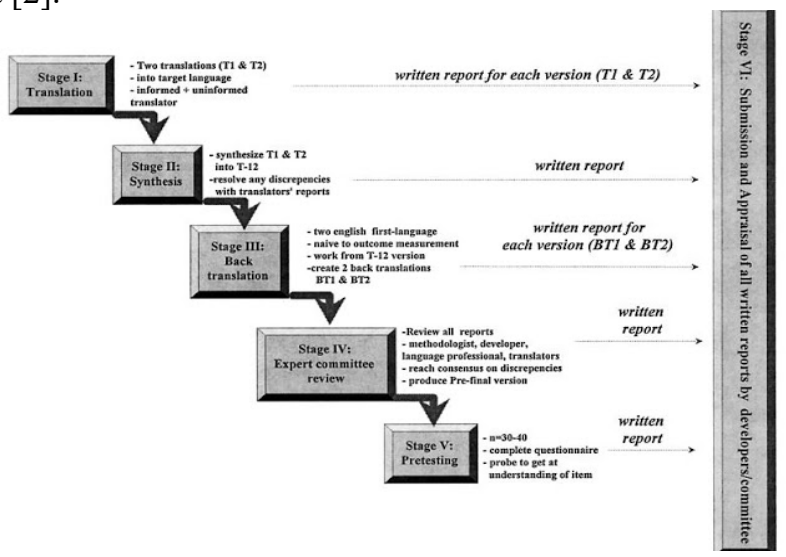

Fig. 1. Cross-cultural Adaptation

In the first stage, translation is done by two people called T1 and T2. The task of adapting the Passion Scale measurement tool is translated by the group first as T1. The T2 is served by Nisa Anggina Lubis, an Indonesian student who is majoring in anthropology at the Australian National University. After the translation process from English to Indonesian is carried out by $\mathrm{T} 1$ and T2, entering the second stage, the synthesis process. This stage synthesizes the results of $\mathrm{T} 1$ and $\mathrm{T} 2$. The translation is done by comparing the results of $\mathrm{T} 1$ and $\mathrm{T} 2$ to the original measuring instruments, then the group selects and corrects the sentences of the translation results which are most suitable for use. The result of the translation will be T-12.

The next process is back translation, which is carried out by two languages, both of which are completely unaware of the construct and item of the original measuring instrument. In this process two languages will translate the results from T-12 back into English. The aim is to see whether the synthesis results at T-12 reflect the same results as the original item if translated into the original language. The results of this back translation will be BT1 and BT2. BT1 is carried out by British citizens who live and work in Indonesia, namely Kay Norfolk. BT2 was conducted by Eria Desomsoni, an Indonesian citizen who completed postgraduate studies at Saint Louis University, USA. Both translators do not have a background in psychology, so the results of the translation on the back translation will not cause bias.

All results of the translation will be given later to the expert committee to conduct a review and produce equivalences across cultures. The expert reviewing the group was Martina Dwi Mustika, a psychology lecturer at the University of Indonesia, who currently lives in Sydney, Australia. The next expert on the expert committee was Debora Eflina Purba, a lecturer in psychology at the University of Indonesia. The next process is the adaptation of measuring instruments using a pretest which can also be called a readability test. Before the adaptation results are agreed to be used, then readability tests should be carried out to see whether the 
adaptation results which have gone through several stages able to be understood and interpreted by the target participants whether gaining expected results or not [2].

\section{Measurement}

\subsection{Passion}

Passion Scale has 7 items for harmonious passion and 7 items for obsessive passion. The scale on the Passion Scale uses a Likert-type scale consisting of 1 (highly inappropriate) to 7 (very appropriate) [1]. Tests through exploratory factor analysis (EFA) and confirmatory factor analysis (CFA) are carried out on the Passion Scale. EFA is done first by using 34 items, then items that have a weak score on EFA are eliminated and produce 14 items ( 7 items each) with the strongest score, with results in two-factor solutions showing 5.62 and 2.05 [6]. After obtaining 14 items, a CFA test was carried out, which also produced coherent data on both types of scale, named x2 $(76, \mathrm{~N}=235)=171.70, \mathrm{p}<.001$ (non-normed fit index [NNFI] $=.912$, comparative fit index $[\mathrm{CFI}]=.926$, root-mean-square error of approximation $[$ RMSEA $]=.073$ [6]. To avoid social desirability, the adaptation of this measuring instrument uses a Likert scale -type consisting of 1 (very inappropriate) to 6 (very appropriate).

\subsection{Reliability}

There are several techniques in measuring the reliability of a measuring instrument; they are test-retest, alternate forms, and internal consistency [12]. In the Passion Scale research the technique which will be used is to seek the level of internal consistency, which is a method measures the level of correlation between items in a measuring instrument [12]. Internal consistency is measured using alpha coefficient (Cronbach's Alpha).

The Cronbach's Alpha reliability score is $0-1$ [12]. The reliability score obtained for harmonious passion is 0.851 and the reliability score for obsessive passion is 0.719 . Cronbach's Alpha scores are said to be reliable if the scores are in the range 0.7-0.8 [12]. The interesting things found in the Passion Scale measuring instrument which was adapted in Indonesia with the original measuring instrument had different results for the reliability test. On the original measuring instrument the reliability score for harmonious passion was 0.79 and obsessive passion was 0.89 [6]. The reliability value of obsessive passion is higher in the original measuring instrument. In this study the reliability score obtained for harmonious passion is 0.851 and obsessive passion is 0.719 . Higher reliability scores for harmonious passion after going through the process of adaptation. This difference shows that passion is a type of measurement that can be adapted to the cultural context of the research conducted.

\subsection{Validity}

The process of measuring validity is the process of collecting and evaluating data as the evidence measuring instrument validity [13]. Observation the validity used in the Passion Scale is for constructing validity, which is testing the suitability of the items in the variable. The construct validity test is carried out by using the factor analysis method, Exploratory Factor Analysis (EFA) and Confirmatory Factor Analysis (CFA). EFA is a test by extracting factors and determining factors can be survived, and CFA is done to test dimensionality as a reference to test the dimensionality test of measuring instruments, CFA also provides 
information on whether the observed covariance fit model with the measured variables to measure passion using this measuring tool [13]. At this stage, the analysis was carried out using the LISREL program version 8.70 [14].

In the EFA Kaiser-Meyer-Olkin (KMO) results obtained for the Passion Scale measuring instrument is 0.823 , this score approaches the score 1 which indicates that the sample used in the study is in accordance with this measuring instrument. The results from EFA show that the passion gauge is divided into 4 components. Component 1 consists of 7 items HP1, HP2, HP3, HP 4, HP5, HP6, and HP7. For component 2 consists of 5 items OP1, OP2, OP3, OP5, and OP6. For component 3 has 1 item, OP 4 and component 4 consists of 1 item, OP 7.

CFA test results are divided on 7 items. This model is fit with several criteria which are appropriate. Value of RMSEA said to be fit when its value ranges between 0.05-0.10 and poor fit if the value generated is above 0.10 [15]. Harmonious passion produces p-value: 0.07163 , RMSEA: 0.079 , df: 10 . The result of loading factor of harmonious passion with t-value $>1.96$ and no minus value is found so that the seven items of harmonious passion are maintained. Factor loading on harmonious passion, HP1: 5.93, HP2: 7.81, HP3: 8.44, HP4: 10.62, HP5: 7.42, HP6: 7.81, and HP7: 6.36 .

In the path diagram, obsessive passion produces p-value: 0.000, RMSEA: 0.174, df: 14 According to Hooper the obsessive passion construct is said to be unfit because it has an RMSEA above 0.10[15]. So this test is repeated to remove 2 items that have a t-value $<1.96$ and have a minus value. The item decision was also eliminated based on the results of the EFA that had been done before. These items are OP4 and OP7 items. After the 2 items are eliminated, the loading factor can be in obsessive passion, OP1: 9.99; OP2: 11.21; OP3: 9.85; OP: 56.36; OP6: 8.80 and the p-value becomes 0.13466 . The lambda-x and std.error values for obsessive passion are as follows, OP1: $0.81,0.08$; OP2: 0.88, 0.08; OP3: 0.80, 0.08; OP5: 0.58, 0.09; OP6: 0.74, 0.08 .

\section{Results and Discussion}

\subsection{Item Analysis}

Internal consistency seen from the Corrected Item Total Correlation (CRIT) score which is more than or equal to 0.3 [12].

Table 1. Corrected Item Total Correlation Harmonious Passion

\begin{tabular}{lcccc}
\hline Item & CRIT & Lambda & Error & Researcher's Decision \\
\hline HP 1 & 0.577 & 0.56 & 0.09 & Items maintained \\
HP 2 & 0.700 & 0.69 & 0.09 & Items maintained \\
HP 3 & 0.652 & 0.73 & 0.09 & Items maintained \\
HP 4 & 0.718 & 0.87 & 0.08 & Items maintained \\
HP 5 & 0.542 & 0.66 & 0.09 & Items maintained \\
HP 6 & 0.607 & 0.69 & 0.09 & Items maintained \\
HP 7 & 0.533 & 0.59 & 0.09 & Items maintained \\
\hline
\end{tabular}

Table 2. Obsessive Passion

\begin{tabular}{ccccc}
\hline Item & CRIT & Lambda & Error & Researcher's decision \\
\hline OP 1 & 0.685 & 0.81 & 0.08 & Items maintained \\
OP 2 & 0.626 & 0.84 & 0.08 & Items maintained \\
OP 3 & 0.633 & 0.80 & 0.08 & Items maintained \\
\hline
\end{tabular}




\begin{tabular}{ccccc}
\hline Item & CRIT & Lambda & Error & Researcher's decision \\
\hline OP 4 & 0.075 & 0.08 & 0.10 & Items discarded \\
OP 5 & 0.600 & 0.66 & 0.09 & Items maintained \\
OP 6 & 0.623 & 0.79 & 0.08 & Items maintained \\
OP 7 & -0.047 & -0.02 & 0.10 & Item discarded \\
\hline
\end{tabular}

\subsection{Re-Testing Reliability and Validity}

Re-testing the reliability of obsessive passion is 0.865 . This test was carried out after the researchers tested 5 items were retained. This retest resulted in the latest Corrected item total correlation, as follows:

Table 3. Corrected Item Total Correlation Obsessive Passion

\begin{tabular}{ccccc}
\hline Item & CRIT & Lambda & Error & Researcher's decision \\
\hline OP 1 & 0.698 & 0.81 & 0.08 & Items maintained \\
OP 2 & 0.714 & 0.88 & 0.08 & Items maintained \\
OP 3 & 0.697 & 0.80 & 0.08 & Items maintained \\
OP 5 & 0.597 & 0.58 & 0.09 & Items maintained \\
OP 6 & 0.730 & 0.74 & 0.08 & Items maintained \\
\hline
\end{tabular}

For re-testing the EFA after removing 2 items produced 2 components in accordance with the division of the dualistic model of passion theory. The first component 1 is harmonious passion consists of 7 items; HP 1, HP 2, HP 3, HP 4, HP 5, HP 6, HP 7. The second component consists of 5 obsessive passion items; OP 1, OP 2, OP 3, OP 5, and OP 6.

In the re-validity testing, while the 5 obsessive passion items produce p-value: 0.13466 , RMSEA: 0.082, df: 4. The result of obsessive passion loading factor, OP1: 9.99, OP2: 11.21, OP3: 9.85 , OP5: 6.36 , and OP6: 8.80 .

Table 4. Indonesian version of the Passion Scale

\begin{tabular}{|c|c|}
\hline Original version & Adaptation result \\
\hline \multicolumn{2}{|l|}{ Harmonious Passion } \\
\hline $\begin{array}{l}\text { a. This activity allows me to live a variety of } \\
\text { experiences }\end{array}$ & $\begin{array}{l}\text { Pekerjaan ini memberikan saya pengalaman yang } \\
\text { beragam }\end{array}$ \\
\hline $\begin{array}{l}\text { b. This activity allows me to live memorable } \\
\text { experiences. }\end{array}$ & Pekerjaan ini memberikan pengalaman yang berkesan \\
\hline $\begin{array}{l}\text { c. The new things that I discover with this activity } \\
\text { allow me to appreciate it even more }\end{array}$ & $\begin{array}{l}\text { Hal baru yang saya temui dalam pekerjaan ini } \\
\text { menjadikan saya lebih menghargai pekerjaan }\end{array}$ \\
\hline $\begin{array}{l}\text { d. This activity reflects the qualities I like about } \\
\text { myself. }\end{array}$ & $\begin{array}{l}\text { Pekerjaan ini mencerminkan kualitas yang saya suka } \\
\text { dari diri saya }\end{array}$ \\
\hline $\begin{array}{l}\text { e. This activity is in harmony with the other activities } \\
\text { in my life }\end{array}$ & $\begin{array}{l}\text { Pekerjaan ini memiliki keselarasan dengan aktifitas } \\
\text { lain di hidup saya. }\end{array}$ \\
\hline f. I am completely taken with this activity. & nemiliki komitmen yang penuh pada pekerjaan \\
\hline g. For me it is a passion, that I still manage to control & $\begin{array}{l}\text { Kecintaan saya pada pekerjaan ini masih dapat saya } \\
\text { kendalikan. }\end{array}$ \\
\hline \multicolumn{2}{|l|}{ Obsessive Passion } \\
\hline a. I cann & ak bisa lepas dari pekerjaan saya \\
\hline $\begin{array}{l}\text { b. The urge is so strong. I can't help myself from } \\
\text { doing this activity. }\end{array}$ & $\begin{array}{l}\text { Dorongan terhadap pekerjaan ini sangat kuat. Saya } \\
\text { ingin selalu melakukan pekerjaan ini }\end{array}$ \\
\hline $\begin{array}{l}\text { c. I have difficulty imagining my life without this } \\
\text { activity }\end{array}$ & $\begin{array}{l}\text { Saya sulit membayangkan hidup saya tanpa pekerjaan } \\
\text { ini }\end{array}$ \\
\hline I am emotionally dependent on this activity. & Saya secara emosional bergantung pada pekerjaan ini \\
\hline e. I have almost an obsessive feeling for this activity & $\begin{array}{l}\text { Saya memiliki keterikatan yang erat terhadap } \\
\text { pekerjaan ini }\end{array}$ \\
\hline
\end{tabular}




\subsection{Norms Organization}

The norms organization this study uses the criterion norm reference, where there is a middle value which determines the criteria and categories of norms. Norms are organized using the total number of item scores for each sample. Through the total number of scores, later refer the average score, minimum score, and maximum score to determine the criteria. The total score of harmonious passion shows an average score of 32.8185, minimum score of 18 , and maximum score of 42 . Therefore, respondents can be classified as harmonious passion if it has a score of 32-42 and not classified as harmonious passion if it has a score of 18-31. The number of scores for obsessive passion gets an average score of 18.0614, a minimum score of 5, and a maximum score of 30. Individuals who are in the category of obsessive passion are those who have a score of 5-17, and those who do not belong to obsessive passion are those who have a score of 18-30.

The 24th respondent is an employee of a digital expertise company. The respondent has worked less than 5 years in this company. The 24th respondent was classified as a harmonious passion employee with a total score of 35 and was not classified as an employee with an obsessive passion (score 22). The 81st respondent is a contract employee who works as a general affair in a media company. This employee has worked for less than 5 years and can be categorized as an employee with an obsessive passion with a total score of 16 and classified as having no harmonious passion with a total score of 28 .

The adaptation of the Passion Scale measuring instrument in this study involved two tests; EFA and CFA. EFA testing involves 14 passion items testing fulfilling the fit criteria in RMSEA. This can be considered fit. The results from EFA show that the passion gauge is divided into 4 components. The elimination process resulted in a total of 12 items being maintained, 2 items in obsessive passion because they were not yet fit, while in harmonious passion 7 items got fit results. The results show that the 12 items measure one latent variable, namely passion. So the measuring instrument adapted in this study meets the assumption of various dimensionalities.

Regarding the number of items, there is no standard that states the limit on the number of items that can be said to be large or small, but the results of the data can be categorized as harmonious or not and obsessive or not. The design of the passion measuring instrument norms is based on the criterion norm reference.

\section{Conclusion}

The aim of the study is to adapt the passion scale measuring instrument based on the theory put forward by Vallerand [4], because it is considered able to describe passion as a psychological variable. However, testing is still needed to prove that the adaptation of the measuring instrument has a valid construct.

The adaptation process of the passion scale measuring instrument provides the results of calculating the validity of the measuring tool and testing the various dimensionality based on the confirmatory factor analysis (CFA) method which confirms that the construct of the passion scale measuring instrument proposed by Vallerand proved to be valid [4]. The results from EFA show that the passion gauge is divided into 4 components. This study also tested using the CFA method to test the assumption of various dimensionality. CFA testing on 14 items of passion scale measuring instrument, the subscale harmonious passion, gave fit results at $p$-value $>0.05$ of 0.7163 , while subscale obsessive passion gave fit results at $p$-value $>0.05$ 
of 0.13466 . The elimination of 2 items in obsessive passion generate 12 valid items passion scale items in total, therefore the CFA test results show that the model used is fit with the data. In other words the items in the measuring instrument adapted in this study are confirmed and fit to measure passion and prove the adapted passion gauge meets various dimensionality assumptions.

The results showed that the Passion Scale measuring instrument which was adapted in Indonesia with the original measuring instrument had different results for the reliability test, which showed the reliability score on the original measuring instrument for harmonious passion and obsessive passion [6]. The value of obsessive passion reliability is higher on the original measuring instrument when compared to the passion scale measuring instrument in the research that has been carried out. This shows that the passion scale measuring instrument is a type of measurement which can be adjusted to the cultural context of the research carried out.

Researchers design the passion measuring instrument norms later based on the criterion norm reference, they are conducting tests which focus on what can be done and what individuals know rather than how they are compared to others (usually to measure certain skills) [12]. It can be concluded that the measuring instrument adapted in this study is a reliable, valid passion scale measuring instrument, which has models and items that are fit and contextual with employees in Indonesia.

\section{References}

[1] H. W. Marsh et al., "Passion: Does one scale fit all? Construct validity of two-factor passion scale and psychometric invariance over different activities and languages," Psychol. Assess., vol. 25, no. 3, pp. 796-809, 2013, doi: 10.1037/a0032573.

[2] M. B. Beaton, D. E., Bombardier, C., Guillemin, F., \& Ferraz, "Guidelines for the Process of Cross-Cultural Adaptation of Self-Report Measures," Spine (Phila. Pa. 1976)., vol. 25, no. 24, pp. 3186-3191, 2001, doi: 10.1097/00007632-20001215000014.

[3] D. Zigarmi, K. Nimon, D. Houson, D. Witt, and J. Diehl, "Beyond engagement:Toward a framework and operational definition for employee work passion," Hum. Resour. Dev. Rev., vol. 8, no. 3, pp. 300-326, 2009, doi: 10.1177/1534484309338171.

[4] N. Vallerand, R. J., \& Houlfort, "Passion at work: Toward a new conceptualization," in Emerging perspectives on values in organizations, D. D. S. \& D. P. S. In S. W. Gilliland, Ed. Greenwich: Information Age Publishing., 2003, pp. 175-204.

[5] I. Katrine Birkeland, A. M. Richardsen, and A. Dysvik, "International Journal of Stress Management The Role of Passion and Support Perceptions in Changing Burnout: A Johnson-Neyman Approach The Role of Passion and Support Perceptions in Changing Burnout: A Johnson-Neyman Approach," Int. J. Stress Manag., 2017, [Online]. Available: http://dx.doi.org/10.1037/str0000057.

[6] R. J. Vallerand et al., "Les Passions de 1'Âme: On Obsessive and Harmonious Passion,” J. Pers. Soc. Psychol., vol. 85, no. 4, pp. 756-767, 2003, doi: 10.1037/00223514.85.4.756.

[7] R. J. Vallerand, "The Psychology of Passion," Psychol. Passion, 2015, doi: 10.1093/acprof:oso/9780199777600.001.0001.

[8] R. J. Vallerand, “On the psychology of passion: In search of what makes people's lives most worth living," Can. Psychol., vol. 49, no. 1, pp. 1-13, 2008, doi: 10.1037/0708- 
5591.49.1.1.

[9] R. J. Vallerand, Chapter Three: On passion for life activities: The dualistic model of passion, 1st ed., vol. 42, no. 10. Elsevier Inc. 2010, 2010.

[10] S. G. Trépanier, C. Fernet, S. Austin, J. Forest, and R. J. Vallerand, "Linking job demands and resources to burnout and work engagement: Does passion underlie these differential relationships?," Motiv. Emot., vol. 38, no. 3, pp. 353-366, 2014, doi: 10.1007/s11031-013-9384-z.

[11] S. Cozby, P. C., \& Bates, Methods in behavioral research, Thirteenth. New York: McGraw-Hill Education, 2018.

[12] E. . Cohen, R. J., Swerdlik, M. E, Sturman, Psychological testing and assessment: An introduction to tests and measurement., Eighth. New York: McGraw-Hill Education, 2013.

[13] M. E. Cohen, R. J., \& Swerdlik, Psychological testing and assessment: An introduction to tests and measurement, Thirthteen. McGraw-Hill Education, 2018.

[14] \& D. S. Joreskog, K.G., LISREL 8: User's Reference Guide. Chicago: Scientific Software International, Inc, 1996.

[15] D. Hooper, J. Coughlan, and M. R. Mullen, "Structural equation modelling: Guidelines for determining model fit," Electron. J. Bus. Res. Methods, vol. 6, no. 1, pp. 53-60, 2008, doi: 10.21427/D79B73. 